Article

\title{
Prospects of Using Termite Mound Soil Organic Amendment for Enhancing Soil Nutrition in Southern Africa
}

\author{
Kafula Chisanga ${ }^{1,2, *}$, Ernest R. Mbega ${ }^{1,2}$ and Patrick A. Ndakidemi ${ }^{1,2}$ \\ 1 Department of Sustainable Agriculture, The Nelson Mandela African Institution of Science and Technology, \\ P.O. Box 447, Arusha 23311, Tanzania; ernest.mbega@nm-aist.ac.tz (E.R.M.); \\ patrick.ndakidemi@nm-aist.ac.tz (P.A.N.) \\ 2 Centre for Research, Agriculture Advancement, Teaching Excellence and Sustainability (CREATES) in Food \\ and Nutrition Security, The Nelson Mandela African Institution of Science and Technology, P.O. Box 447, \\ Arusha 23311, Tanzania \\ * Correspondence: chisangak@nm-aist.ac.tz; Tel.: +255-783-640-428
}

Received: 22 January 2020; Accepted: 5 April 2020; Published: 20 May 2020

\begin{abstract}
Termite mound soils are reportedly utilized as an alternative to NPK fertilizers by cash constrained smallholder farmers in some parts of Southern Africa. However, there is limited knowledge regarding their mineral nutritional value. The intention of this work was therefore to investigate the macro and micronutrient composition of different sections of the termite mounds; top, base and neighboring areas. The study approach involved physical and chemical analysis of 36 sites across Pemba and Choma districts in Southern Zambia through collection of soil samples in triplicate at $0-20 \mathrm{~cm}$ depth, using a soil auger. Findings revealed that the soil $\mathrm{pH}$ had elevated levels in the base segments of the termite mounds compared with the top and the neighbouring soils. However, elevated N, P and K levels were recorded in the top sections with significant differences $(p<0.05)$ in clay and silt composition observed. Additionally, metallic micronutrients, $\mathrm{Cu}$ and $\mathrm{Zn}$ were also found to be elevated in termite mounds in contrast to surrounding soils. We concluded that top termite mound soil should be considered as part of an integrated nutrient management strategy by financially challenged smallholder farmers cultivating in light textured soils of southern Africa.
\end{abstract}

Keywords: soil conditioner; soil fertility; soil nutrient bioavailability; soil $\mathrm{pH}$; soil physical and chemical properties

\section{Introduction}

The Food and Agriculture Organization of the United Nations reports that soil fertility management practices are a major barrier to agricultural production in developing countries [1]. This is further exacerbated by high input costs especially mineral fertilizer which is a critical ingredient in crop production especially for the principal cash and basic crops like maize. Umar et al. [2] also affirms that declining soil fertility in sub-Saharan Africa (SSA) continues to reduce soil productivity and is a major obstacle to addressing problems of food security. In Zambia, for instance, cash strapped smallholder farmers in some agriculture productive districts of Pemba and Choma, in the southern part of the country have often used termite mound soil to fertilize their crops to cushion against the inorganic fertilizer costs [3].

These districts are major contributors to overall crop production in Southern Zambia whose major crops grown by smallholder farmers include maize, cotton, sunflower, sorghum, cowpeas, groundnuts, beans and soybeans [4]. Most of the soils in the area are sandy and pose a great challenge to poor smallholder farmers who have limited financial resources to purchase commercially available 
fertilizer. Such degraded soils have a great impact on the livelihood tactics of the resource constrained smallholder farmers [5].

In Southern Zambia, termite mounds are abundant in Pemba and Choma districts and smallholder farmers have always resorted to using them as a source of alternative fertilizer for crop production $[3,6,7]$. Ruiz-Diez et al. [8] revealed that deficiency in nutrients along with erratic rainfall hold back plant growth. Nziguheba et al. [9] also confirmed that SSA has been well-known for nutrient mining attributable to limited utilization of commercially available fertilizer by some smallholder farmers. Because of this factor, phosphorus deficiency is a key challenge to agriculture production in many countries of SSA [10]. Imbalance of elements such as P affects nodule formation for the legume crops establishment including $\mathrm{N}_{2}$ fixation and plant matter production [11]. We argue here that having information on the nutrient status of the termite mound is crucial for advising on the sections which could be appropriate to use as soil amendment material in agricultural production and as a component of integrated nutrient management (INM) system at smallholder farmer level especially in the developing world. From the point of view of soil science, termite mounds are rich in macro and micro nutrients due to the termite bioturbation activities that enhances significantly exchangeable cations $(\mathrm{K}, \mathrm{Ca}, \mathrm{Mg})$, organic matter, soil $\mathrm{pH}$ and micro nutrients such as $\mathrm{Fe}, \mathrm{Zn}$ and $\mathrm{Cu}$ resulting from the material they collect, ingest and excrete [12].

Until today, studies conducted in Zambia have concentrated on general termite mound soil characterization with little attention on the status of the part of the termite mounds that provide better nutrients for crop production. The current practice by the cash constrained smallholder farmers has been collecting soils from anywhere around the termite mound and applying it directly on to the fields, either solely or in combination with cattle manure and commercially available fertilizer [6]. The smallholder farmers have limited knowledge as to which sections of the termite mounds holds' better fertility. Thus gaining knowledge on the best collection areas could be a game changer in providing the much needed $\mathrm{N}$ and $\mathrm{P}$ nutrients for improved crop production and productivity for future integrated soil fertility management (ISFM) options at smallholder farm level in southern Africa.

Our work, therefore, attempts to discuss the unknown fertility status potentials of the top or base termite mound soil used in agricultural production by financially challenged smallholder farmers in Southern Zambia as part of a traditional integrated nutrient management strategy. In this regard, the objective of the current study was to evaluate soil properties and illustrate differences in their composition, both chemical and physical arising from the top sections of the termite mound to the basement and into the neighbouring areas. We envisage that for the future, the information generated could be useful in soil fertility management decisions for agricultural production, from the smallholder farmer perspective located in similar environments in southern Africa. Accordingly, we hypothesized that different sections of termite mounds have varying nutrient levels and thus may have auxiliary effects when applied as a soil amendment in soils lacking organic matter or light textured soils for boosting plant growth.

\section{Materials and Methods}

\subsection{Study Site}

The study was conducted in southern province of Zambia in Pemba $\left(16^{\circ} 32^{\prime} 0^{\prime \prime}\right.$ South, $27^{\circ} 22^{\prime} 0^{\prime \prime}$ East) and Choma (Longitudes $26^{\circ} 30^{\prime} 0^{\prime \prime}$ and $27^{\circ} 30^{\prime} 0^{\prime \prime}$ East of Greenwich and Latitudes $16^{\circ}$ and $17^{\circ} 45^{\prime} 0^{\prime \prime}$ South). Pemba and Choma districts (Figure 1) fall in Agro Ecological Zone (AEZ) IIa of the country where maximum rainfall ranges from $800-1000 \mathrm{~mm} \mathrm{yr}^{-1}$ and the dominant soils are the Lixisols, Regosols, Leptosols and Vertisols [4]. The Pemba climate is classified as Cwa by the Köppen-Geiger syste- - zone of climate characterized by warm and temperate conditions. In comparison to winter, the summers have much more rainfall. Mean annual temperature is $19.5{ }^{\circ} \mathrm{C}$ while mean annual precipitation is $848 \mathrm{~mm}$. The driest month is July, with $0 \mathrm{~mm}$ of rainfall. In December, the precipitation reaches its climax, with an average of $219 \mathrm{~mm}$. The warmest month of the year is November, with a 
mean temperature of $23.1^{\circ} \mathrm{C}$ and the coldest month is July $\left(14.0^{\circ} \mathrm{C}\right)$. Just like Pemba, the climate in Choma is classified as Cwa following the Köppen-Geiger system coupled with warm weather scenarios. In winter, there is much less rainfall than in summer. Annual mean temperature is $18.7{ }^{\circ} \mathrm{C}$ while that of rainfall is $805 \mathrm{~mm}$, with July being the driest ( $0 \mathrm{~mm}$ of rain). Most precipitation falls in January $(202 \mathrm{~mm})$. The warmest month of the year is November $\left(22.4^{\circ} \mathrm{C}\right)$. In July, the mean temperature is $12.9{ }^{\circ} \mathrm{C}$ and is considered the lowest of the whole year. The principal vegetation in southern province of Zambia is the Kalahari woodlands, characterized by Mopane with patches of miombo woodland, acacia species and termite mounds [13]. Elevation range of the undulating surface is from 1200-1350 m above sea level [14].

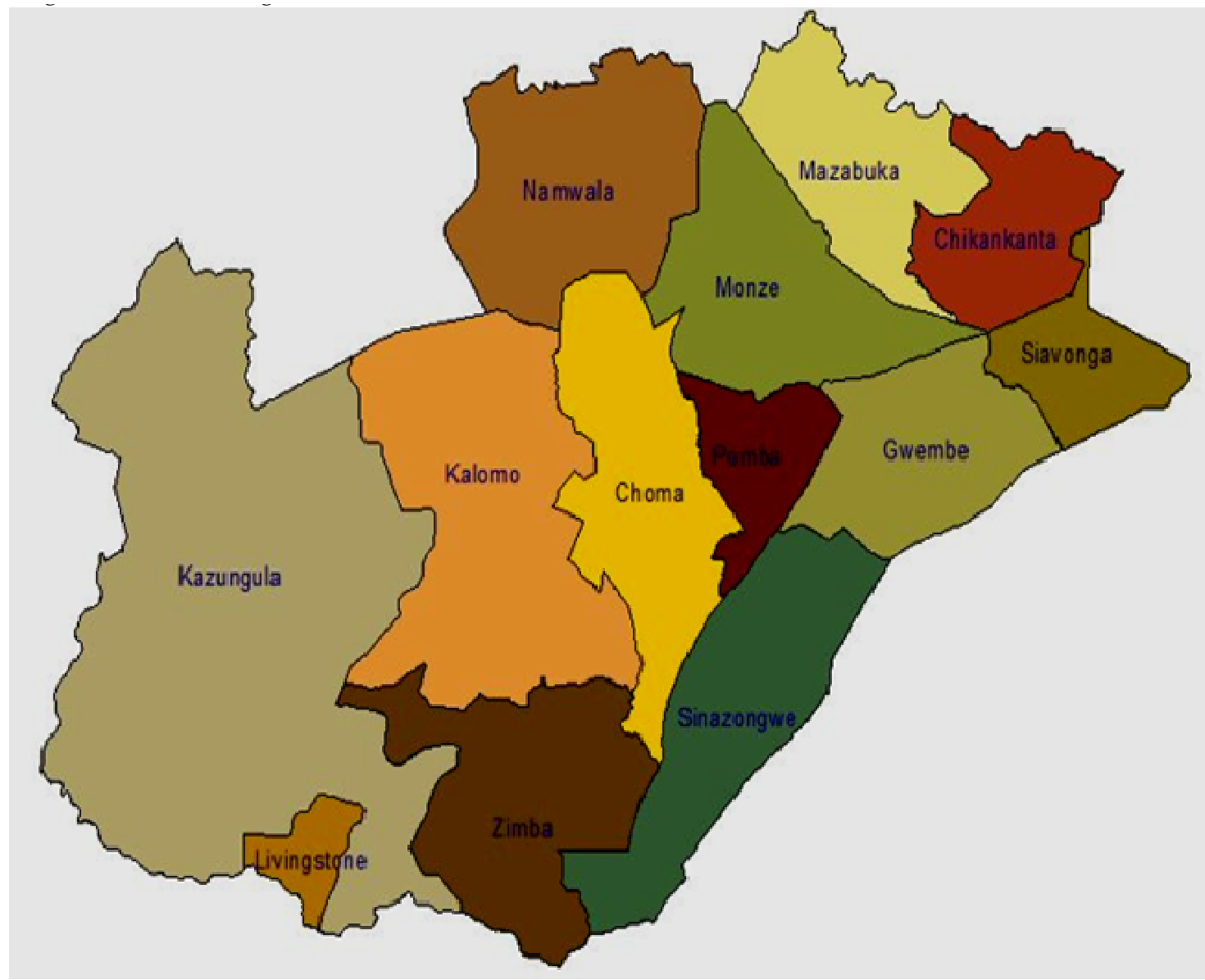

Figure 1. Study location-Choma and Pemba districts in Southern Zambia. (Source: Ministry of Agriculture, Zambia).

\subsection{Termite Mound Sampling Design}

Prior to collection of soil samples from termite mounds, a field research permit was obtained from the IRB (Approval No. 2018-Feb-046). Subsequently, a rapid assessment of the study areas was undertaken during the cropping season to identify the termite mounds which were in use for crop production by the smallholder farmers. Six plots measuring $500 \times 20 \mathrm{~m}$ were marked out in each study district, with corners set and bench marked using wooden pegs. All the termite mounds in the area both used and non-used were counted and two termite mounds were selected at random for sampling [15]. Soil samples $(n=36)$ were taken at the depth of $0-20 \mathrm{~cm}$ from three different points; top, base and $10 \mathrm{~m}$ away from the centre of the termite mounds using a soil auger [16] (Figure 2). A composite sample made up of three subsamples was collected. Thereafter, a representative sample of about $1 \mathrm{~kg}$ of soil was packed in a plastic, labelled and taken to laboratory. All the collected soil samples were air dried and passed through a $2 \mathrm{~mm}$-sieve. 


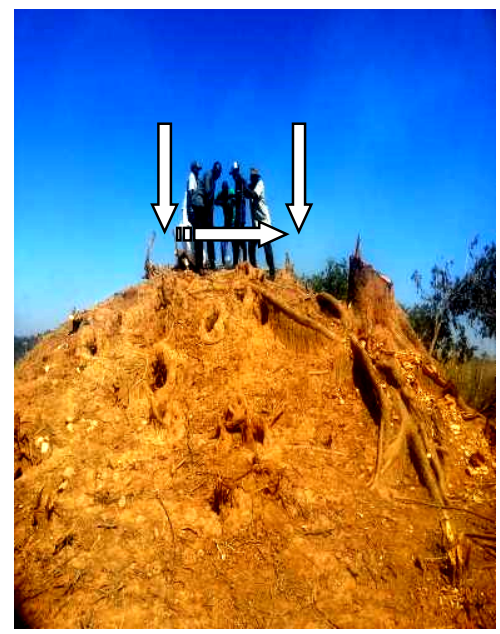

(A)

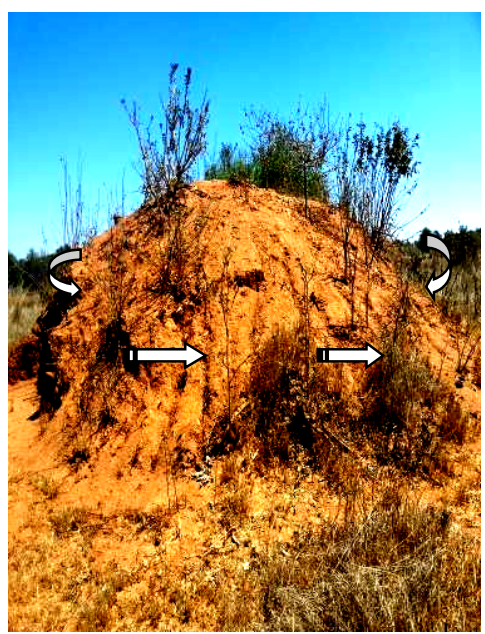

(B)

Figure 2. Photographs of termite mound soil sampling points: (A) Soil collection from the top of the termite mound; (B) soil collection along the base of the termite mound.

\subsection{Laboratory Analytics}

The study adopted the standard methods of soil analysis for the parameters of interest as indicated in Table 1. All the laboratory measurements were conducted in triplicate.

Table 1. Summary of methods used for soil analysis.

\begin{tabular}{|c|c|c|c|}
\hline Nutrient Variable & $\begin{array}{c}\text { Units of } \\
\text { Measurement }\end{array}$ & Method Applied & References \\
\hline $\mathrm{pH}$ (water) & $\mathrm{pH}$ & 1:1 (soil: $\left.\mathrm{H}_{2} \mathrm{O}\right)$ & VanReeuwijk [17] \\
\hline Organic Carbon & $\%$ & Walkley and Black & Walkley and Black [18] \\
\hline Total N & $\%$ & Kjeldahl method & Page [19] \\
\hline Available P & $\mathrm{mg} / \mathrm{kg}$ & Bray II (molybdate blue) method, spectrophotometer & Bray and Kurtz [20] \\
\hline Exchangeable K & $\mathrm{mg} / \mathrm{kg}$ & $1 \mathrm{M} \mathrm{NH}_{4} \mathrm{Cl}$, flame photometer & VanReeuwijk [21] \\
\hline Exchangeable $\mathrm{Ca}$ & $\mathrm{cmol} / \mathrm{kg}$ & $1 \mathrm{M} \mathrm{NH}_{4} \mathrm{Cl}$, flame photometer & VanReeuwijk [21] \\
\hline $\begin{array}{l}\text { Exchangeable } \mathrm{Mg}, \\
\mathrm{Cu}, \mathrm{Fe}, \mathrm{Zn}\end{array}$ & $\begin{array}{c}\mathrm{cmol} / \mathrm{kg} \\
\mathrm{mg} / \mathrm{kg}\end{array}$ & $1 \mathrm{M} \mathrm{NH}_{4} \mathrm{Cl}$, atomic absorption spectrophotometer & VanReeuwijk [21] \\
\hline Electrical Conductivity & & Conductivity meter procedure & Raina et al. [22] \\
\hline Cation exchange capacity (CEC) & $\mathrm{cmol} / \mathrm{kg}$ & Exchangeable $\mathrm{K}+\mathrm{Na}+\mathrm{Ca}+\mathrm{Mg}+\mathrm{Al}+\mathrm{H}$ & Page [19] \\
\hline Sand & $\%$ & Hydrometer method & VanReeuwijk [21] \\
\hline Silt & $\%$ & Hydrometer method & VanReeuwijk [21] \\
\hline Clay & $\%$ & Hydrometer method & VanReeuwijk [21] \\
\hline
\end{tabular}

\subsection{Statistical Analysis}

A two-way analysis of variance (ANOVA) using randomised complete block design approach with STATISTICA Version 10 Programme (2011) was employed. Mean significant differences were tested at $95 \%$ confidence interval. The normality and homogeneity of variances was met before the ANOVA (Shapiro-Wilk test). Correlation analysis was further employed to locate the relationship between organic carbon and other available mineral elements (N, P, K, Cu, Fe and $\mathrm{Zn}$ ). The study adopted the factor effects following Wang and DeVogel [23] statistical model for data analysis and was applied as specified below:

$$
Y_{i j k}=\mu+\alpha_{i}+\beta_{j}+(\alpha \beta)_{i . j}+\varepsilon_{i j k} \text { for } \mathrm{i}=1,2 \ldots \mathrm{b} ; \mathrm{j}=1,2 \ldots \mathrm{t} ; \mathrm{k}=1, \ldots, \mathrm{nij}
$$

where $Y_{i j k}=$ observations; $\mu$ = grand mean; $\alpha_{i}=$ main effects of factor $\mathrm{A} ; \beta_{j}=$ main effects of factor $\mathrm{B}$; $(\alpha \beta)_{i . j}=$ interaction effects between factor $A$ and $B ; \varepsilon_{i j k}=$, error term. The site (district) and the soil collection points (top, base and $10 \mathrm{~m}$ away from termite mound) were used as predictor variables instead of $\mathrm{pH} ; \mathrm{N} ; \mathrm{P} ; \mathrm{K} ; \mathrm{Ca} ; \mathrm{Mg} ; \mathrm{O} . \mathrm{C} ; \mathrm{CEC} ; \mathrm{EC} ; \mathrm{Zn} ; \mathrm{Cu} ; \mathrm{Fe}$ and clay, silt and sand that represented response variables. 


\section{Results}

\subsection{Soil $p H$}

The soil $\mathrm{pH}$ in the top termite mound averaged 6.53 while that of the base termite mound 7.05 and in soil samples from $10 \mathrm{~m}$ away from the termite mound $\mathrm{pH}$ values averaged 5.08. Generally, Pemba had higher $\mathrm{pH}$ values than Choma site.

\subsection{Total $N$}

Total $\mathrm{N}$ in the top termite mound soil averaged $0.08 \%$ while base termite mound soil and that collected $10 \mathrm{~m}$ away from it indicated an average of $0.07 \%$ and $0.06 \%$ respectively. The proposed threshold level for $\mathrm{N}$ was $0.20 \%$ [24]. Soil having critical levels below the suggested value is considered deficient in plant available $\mathrm{N}$ (Table 2).

Table 2. Comparison of soil chemical parameter values and treatment effects across studied sites.

\begin{tabular}{|c|c|c|c|c|c|c|}
\hline District & $\mathrm{pH}$ & $\mathbf{N}(\%)$ & $P\left(\mathrm{mg} \mathrm{kg}^{-1}\right)$ & $\mathrm{K}\left(\mathrm{cmol} \mathrm{kg} \mathrm{kg}^{-1}\right)$ & $\mathrm{Ca}\left(\mathrm{cmol} \mathrm{kg}^{-1}\right)$ & $\mathrm{Mg}\left(\mathrm{cmol} \mathrm{kg}^{-1}\right)$ \\
\hline Pemba & $6.59 \pm 0.29 a$ & $0.09 \pm 0.01 \mathrm{a}$ & $6.12 \pm 1.11 \mathrm{a}$ & $1.53 \pm 0.31 b$ & $44.91 \pm 13.82 \mathrm{a}$ & $5.64 \pm 1.36 a$ \\
\hline $\begin{array}{l}\text { Choma } \\
\text { SCA }\end{array}$ & $5.85 \pm 0.30 \mathrm{~b}$ & $0.05 \pm 0.00 \mathrm{~b}$ & $4.99 \pm 0.72 \mathrm{a}$ & $74.47 \pm 31.53 a$ & $12.55 \pm 2.93 b$ & $1.01 \pm 0.17 \mathrm{~b}$ \\
\hline $\mathrm{T}$ & $6.53 \pm 0.34 b$ & $0.08 \pm 0.01 \mathrm{a}$ & $8.04 \pm 0.94 b$ & $89.85 \pm 46.32 a$ & $52.58 \pm 19.33 a$ & $4.97 \pm 1.61 \mathrm{~b}$ \\
\hline B & $7.05 \pm 0.19 b$ & $0.07 \pm 0.01 \mathrm{a}$ & $6.34 \pm 1.24 b$ & $23.91 \pm 11.42 \mathrm{ab}$ & $30.53 \pm 6.90 \mathrm{ab}$ & $4.57 \pm 1.45 b$ \\
\hline A & $5.08 \pm 0.31 \mathrm{a}$ & $0.06 \pm 0.01 \mathrm{a}$ & $2.30 \pm 0.42 \mathrm{a}$ & $0.17 \pm 0.05 \mathrm{~b}$ & $3.09 \pm 0.85 b$ & $0.44 \pm 0.09 \mathrm{a}$ \\
\hline \multicolumn{7}{|c|}{ Overall Treatment Effects-F statistics } \\
\hline District & $0.03 *$ & $0.00 *$ & 0.31 & $0.01 *$ & $0.01 *$ & $0.00 *$ \\
\hline SCA & $0.00 *$ & 0.26 & $0.00 *$ & $0.03 *$ & $0.01 *$ & $0.00 *$ \\
\hline District * SCA & 0.6 & 0.85 & 0.95 & $0.03 *$ & $0.03 *$ & 0.05 \\
\hline
\end{tabular}

NB: * Significant at $p \leq 0.05 ; \mathrm{SCA}=$ soil collection area $(\mathrm{n}=36)$, while A, B and T means soil collected $10 \mathrm{~m}$ away, base and top sections of termite mound respectively. Means within the same column followed by the same letter (s) refer to no significance at $(p \leq 0.05)$ based on Tukey's Honest Significance Difference Test.

\subsection{Available P}

The available $\mathrm{P}$ in the top termite mound soil averaged $8.04 \mathrm{mg} \mathrm{kg}^{-1}$ across the two study districts. For the base termite mound soil, $\mathrm{P}$ values averaged $6.34 \mathrm{mg} \mathrm{kg}^{-1}$, while in the surrounding soil, $10 \mathrm{~m}$ away from it, the average value was $2.30 \mathrm{mg} \mathrm{kg}^{-1}$. Overall, Pemba District exhibited highest P content in the top and base termite mound sections including $10 \mathrm{~m}$ away from the structure compared with Choma (Table 2). This was however below the threshold levels for P pegged at $15 \mathrm{mg} \mathrm{kg}^{-1}$.

\subsection{Exchangeable $\mathrm{Mg}$ and $\mathrm{K}$}

Exchangeable $\mathrm{Mg}$ averaged $3.33 \mathrm{cmol} \mathrm{kg}^{-1}$. The proposed threshold value in most agriculture crops was $0.2 \mathrm{cmol} \mathrm{kg}^{-1}$ [24]. In the top termite mound soil, $\mathrm{Mg}$ averaged $4.97 \mathrm{cmol} \mathrm{kg}^{-1}$, suggesting that $\mathrm{Mg}$ supply was adequate to support crop growth. For the base termite mound soil, the Mg average level was $4.57 \mathrm{cmol} \mathrm{kg}^{-1}$ while values for soil collected $10 \mathrm{~m}$ away from it, the $\mathrm{Mg}$ values averaged $0.44 \mathrm{cmol} \mathrm{kg}^{-1}$.

Exchangeable $\mathrm{K}$ in the top termite mound soil averaged $89.85 \mathrm{cmol} \mathrm{kg}^{-1}$ while for the base termite mound soil, the average value was $23.91 \mathrm{cmol} \mathrm{kg}^{-1}$ whereas the soil collected $10 \mathrm{~m}$ away from the termite mounds, exhibited an average of $0.17 \mathrm{cmol} \mathrm{kg}^{-1}$ (Table 2). Termite mound soil had K levels above the critical level of $2 \mathrm{cmol} \mathrm{kg}^{-1}$.

\subsection{Exchangeable $\mathrm{Ca}$}

Exchangeable Ca averaged $52.58 \mathrm{cmol} \mathrm{kg}^{-1}$ in the top termite mound soil of the study sites. Base termite mound soil exhibited an average level of $30.53 \mathrm{cmol} \mathrm{kg}^{-1}$ while the soil $10 \mathrm{~m}$ away from the structure yielded an average of $3.09 \mathrm{cmol} \mathrm{kg}^{-1}$ (Table 2). Recommended threshold for Ca is 5 cmol kg-1. 


\subsection{Organic Carbon (OC)}

OC averaged $1.31 \%$ in the top termite mound soil (Table 3). In the base termite mound soil, the average was $0.97 \%$ whereas in the soil collected $10 \mathrm{~m}$ away from the structure, the average was $0.83 \%$.

Table 3. Comparison of soil chemical parameter values and treatment effects across studied sites.

\begin{tabular}{|c|c|c|c|c|c|c|}
\hline District & O.C (\%) & CEC $\left(\mathrm{cmol} \mathrm{kg}^{-1}\right)$ & $\mathrm{EC}\left(\mu \mathrm{scm}^{-1}\right)$ & $\mathrm{Zn}\left(\mathrm{mg} \mathrm{kg}^{-1}\right)$ & $\mathrm{Cu}\left(\mathrm{mg} \mathrm{kg}^{-1}\right)$ & $\mathrm{Fe}\left(\mathrm{mg} \mathrm{kg}^{-1}\right)$ \\
\hline Pemba & $1.01 \pm 0.05 \mathrm{a}$ & $30.14 \pm 7.67 \mathrm{a}$ & $841.65 \pm 262.36 a$ & $0.91 \pm 0.19 \mathrm{a}$ & $0.81 \pm 0.16 a$ & $18.02 \pm 2.37 \mathrm{~b}$ \\
\hline Choma & $1.07 \pm 0.06 \mathrm{a}$ & $14.18 \pm 2.92 b$ & $90.81 \pm 18.46 b$ & $1.05 \pm 0.16 \mathrm{a}$ & $0.66 \pm 0.13 a$ & $29.19 \pm 1.18 \mathrm{a}$ \\
\hline \multicolumn{7}{|l|}{ SCA } \\
\hline $\mathrm{T}$ & $1.31 \pm 0.02 \mathrm{a}$ & $32.19 \pm 8.92 b$ & $439.99 \pm 111.27 \mathrm{ab}$ & $1.45 \pm 0.21 \mathrm{~b}$ & $0.88 \pm 0.20 \mathrm{~b}$ & $25.84 \pm 3.51 b$ \\
\hline B & $0.97 \pm 0.04 \mathrm{~b}$ & $30.09 \pm 6.98 b$ & $904.48 \pm 391.56 a$ & $1.12 \pm 0.21 b$ & $1.19 \pm 0.08 b$ & $17.63 \pm 2.59 \mathrm{a}$ \\
\hline A & $0.83 \pm 0.04 \mathrm{c}$ & $4.21 \pm 1.06 \mathrm{a}$ & $54.20 \pm 11.96 c$ & $0.36 \pm 0.04 a$ & $0.13 \pm 0.05 a$ & $27.35 \pm 0.88 \mathrm{~b}$ \\
\hline \multicolumn{7}{|c|}{ Overall Treatment Effects-F Statistics } \\
\hline District & 0.12 & $0.03 *$ & $0.00 *$ & 0.44 & 0.31 & $0.00 *$ \\
\hline SCA & $0.00 *$ & $0.00 *$ & $0.01 *$ & $0.00 *$ & $0.00 *$ & $0.00 *$ \\
\hline District * SCA & 0.04 * & 0.25 & 0.01 * & 0.01 * & 0.93 & 0.03 * \\
\hline
\end{tabular}

NB: * Significant at $p \leq 0.05$; SCA $=$ soil collection area $(\mathrm{n}=36)$, while A, B and T means soil collected $10 \mathrm{~m}$ away, base and top sections of termite mound respectively. Means within the same column followed by the same letter (s) refer to no significance at $(p \leq 0.05)$ based on Tukey's Honest Significance Difference Test.

\subsection{Cation Exchange Capacity (CEC)}

CEC averaged $32.19 \mathrm{cmol} \mathrm{kg}^{-1}$ in the top termite mound soil in both study sites (Table 3). Base termite mound soil exhibited CEC average of $30.09 \mathrm{cmol} \mathrm{kg}^{-1}$ whereas soil $10 \mathrm{~m}$ away from it, had an average of $4.21 \mathrm{cmol} \mathrm{kg}^{-1}$. Most sites had CEC above critical value except two sites away from the termite mounds in Pemba and Choma districts which were below $10.0 \mathrm{cmol} \mathrm{kg}^{-1}$, the recommended minimum level.

\subsection{Electrical Conductivity (EC)}

EC values averaged $439.99 \mu \mathrm{sm}^{-1}$ in the top termite mound soil whereupon in the base termite mound soil the average was $904.48 \mu \mathrm{s} \mathrm{cm}^{-1}$. For soils collected $10 \mathrm{~m}$ away from the termite mound, the EC average was $54.20 \mu \mathrm{s} \mathrm{cm}^{-1}$. Generally, the termite mound soil had higher values of EC compared with the surrounding soil across the study districts (Table 3) but adequate to support crop growth.

\subsection{Available $\mathrm{Cu}, \mathrm{Fe}$ and $\mathrm{Zn}$}

Available $\mathrm{Cu}$ in the top termite mound soil averaged $0.88 \mathrm{mg} \mathrm{kg}^{-1}$. For base termite mound soil, the average was $1.19 \mathrm{mg} \mathrm{kg}^{-1}$ while the soil collected $10 \mathrm{~m}$ away from it exhibited an average of $0.13 \mathrm{mg} \mathrm{kg}^{-1}$. All the soils from the termite mounds had greater than threshold value of $0.2 \mathrm{mg} \mathrm{kg}^{-1}$ except for sites in soil collected $10 \mathrm{~m}$ away from the termite mound (Table 3). Available Fe in the top termite mound soil averaged $25.84 \mathrm{mg} \mathrm{kg}^{-1}$. In the base termite mound soil, the average was $17.63 \mathrm{mg} \mathrm{kg}^{-1}$, whereas in the soil $10 \mathrm{~m}$ away from it, Fe content averaged $27.35 \mathrm{mg} \mathrm{kg}^{-1}$. Recommended threshold level for Fe ranges from 0.3 to $10 \mathrm{mg} \mathrm{kg}^{-1}$ [25]. In all the studied soils, the Fe levels were greater than the critical level. Available $\mathrm{Zn}$ in the top termite mound soil averaged $1.45 \mathrm{mg} \mathrm{kg}^{-1}$. The $\mathrm{Zn}$ levels in base termite mound averaged $1.12 \mathrm{mg} \mathrm{kg}^{-1}$ while for soil $10 \mathrm{~m}$ away from it, the average was $0.36 \mathrm{mg} \mathrm{kg}^{-1}$. For Zn (DTPA), the proposed threshold levels was $0.4-0.6 \mathrm{mg} \mathrm{kg}^{-1}$ and any values above $10-20 \mathrm{mg} \mathrm{kg}^{-1}$ were considered as having excess $\mathrm{Zn}$ levels [26]. All the top and base termite mound soils had adequate $\mathrm{Zn}$ levels while soils collected $10 \mathrm{~m}$ away from it exhibited Zn deficiency.

\subsection{Soil Texture}

Particle size distribution (PSD) revealed different composition of sand, clay and silt. Clay on top termite mound > clay on base termite mound > clay $10 \mathrm{~m}$ away from the termite mound (Table 4 ). 
Additionally, there were significant differences $(p<0.05)$ in terms of clay content from different termite mound sections. The mean clay content across the districts was $30.4 \%$.

Table 4. Comparison of soil physical parameter values and treatment effects across studied sites.

\begin{tabular}{cccc}
\hline District & Clay (\%) & Silt (\%) & Sand (\%) \\
\hline Pemba & $33.41 \pm 6.27 \mathrm{a}$ & $7.66 \pm 1.33 \mathrm{a}$ & $41.58 \pm 7.04 \mathrm{a}$ \\
Choma & $27.30 \pm 6.26 \mathrm{a}$ & $7.65 \pm 1.16 \mathrm{a}$ & $45.85 \pm 7.56 \mathrm{a}$ \\
\hline SCA & & \\
T & $56.62 \pm 7.06 \mathrm{a}$ & $5.49 \pm 1.81 \mathrm{~b}$ & $27.30 \pm 6.15 \mathrm{~b}$ \\
$\mathrm{~B}$ & $29.98 \pm 2.54 \mathrm{~b}$ & $11.36 \pm 1.25 \mathrm{a}$ & $41.34 \pm 6.59 \mathrm{ab}$ \\
$\mathrm{A}$ & $4.47 \pm 2.17 \mathrm{c}$ & $6.13 \pm 0.69 \mathrm{~b}$ & $62.51 \pm 10.50 \mathrm{a}$ \\
\hline & Overall Treatment Effects-F Statistics & \\
\hline District & 0.26 & 0.99 & 0.67 \\
SCA & $0.00 *$ & $0.01 *$ & $0.02 *$ \\
District * SCA & 0.83 & 0.08 & 0.93 \\
\hline
\end{tabular}

NB: * Significant at $p \leq 0.05$; SCA = soil collection area $(\mathrm{n}=36)$, while $\mathrm{A}, \mathrm{B}$ and T means soil collected $10 \mathrm{~m}$ away, base and top sections of termite mound respectively. Means within the same column followed by the same letter (s) refer to no significance at $(p \leq 0.05)$ based on Tukey's Honest Significance Difference Test.

For silt composition in this study, the average values were; $5.49 \%, 11.36 \%$ and $6.13 \%$ respectively for the top, base and soil collected $10 \mathrm{~m}$ away from the termite mound with significant differences $(p<0.05)$ being recorded across the collection areas. The average value between districts was $7.66 \%$. Sand levels were higher in the soil collected $10 \mathrm{~m}$ away from the termite mound (62.51\%), followed by base termite mound (41.34\%) and top termite mound (27.30\%) respectively. The mean value across the districts was $43.7 \%$ and differences between districts were non- significant $(p>0.05)$. However, significant differences $(p<0.05)$ were observed within the soil collection areas (Table 4$)$.

\subsection{Relationship between O.C and $N, P, K, C u, Z n$ and $F e$}

There was a significant $(p<0.05)$ positive correlation between O.C and N, P, K and Zn. As for Cu and Fe however, there was no significant correlation with O.C. (Table 5). This may be attributable to the higher amounts of bioturbation activities by mound building termites.

Table 5. Correlation matrix table between organic carbon and key macro and micronutrients in the studied areas.

\begin{tabular}{ccccccc}
\hline Parameter & $\mathbf{N}$ & $\mathbf{P}$ & $\mathbf{K}$ & $\mathbf{C u}$ & $\mathbf{Z n}$ & Fe \\
\hline O.C & $0.34^{*}$ & $0.48^{*}$ & $0.45^{*}$ & $0.33 \mathrm{~ns}$ & $0.51{ }^{*}$ & $0.04 \mathrm{~ns}$ \\
\hline \multicolumn{6}{c}{ Correlations are significant at $p \leq 0.05 ;$ ns $=$ non significant. }
\end{tabular}

\section{Discussion}

Our study showed that the soil $\mathrm{pH}$ values in the different soil collection points were alkaline to moderate levels and could support crop growth. However, a pH value of 4.3 could be detrimental to crop growth and would call for lime application to raise $\mathrm{pH}$ to acceptable levels for crop production. Chapoto et al. [4] reported that acceptable $\mathrm{pH}$ levels for most crops are 5.5-5.8 and at these scales there is no advantage from liming. In addition, Fairhurst [24] reported that $\mathrm{P}$ availability is greatest at $\mathrm{pH}$ 5.5-7.0. Furthermore, soil organisms required for $\mathrm{N}$ mineralization function best at soil $\mathrm{pH} 5.5-6.5$ and at this level, all micronutrients, except Mo, are more available from pH 5.5 to 6.0. Mn and Fe toxicity is also drastically reduced in this range.

Though slightly higher average percentage of total $\mathrm{N}$ was found in the top termite mound soil compared with base termite mound soil and soil collected $10 \mathrm{~m}$ away from it, this was however 
marginally below the proposed critical threshold. Sarcinelli et al. [16] reported that higher values of $\mathrm{N}$ in termite mounds may be attributed to fine organic material (twigs, grass etc.) resulting from nest building activities of the ants. In any case, if the smallholder farmers in Pemba and Choma study districts of Southern Zambia with little capacity to purchase inorganic fertilizer continue using the termite mound soil as an amendment, it would be more beneficial for them to enhance $\mathrm{N}$ levels through application of top and/or base termite mound soil combined with other organic resources such as cattle manure and implementation of crop rotation with legume crops that may involve common beans, soybeans, groundnuts, cowpeas, pigeon peas etc. In such a situation, warranted corrective measures for enhanced $\mathrm{N}$ levels would include application of top or base termite mound soil as there were no significant differences $(p>0.05)$ between the two sections with regard to $\mathrm{N}$ content. However, for smallholders who would afford commercially available fertilizers, combining with termite mound soil may be the best strategy for boosting $\mathrm{N}$ availability. Studies conducted by Mtambanengwe et al. [27] in Zimbabwe reported that combination of $\mathrm{N}$ mineral fertilizers and organic resources increased the organic matter loading in the soil which often resulted in farmers achieving high crop yields on coarse sandy soils. Ndakidemi and Semoka [28] in a similar study, in Tanzania, recommended application of organic and/or inorganic fertilizers where $\mathrm{N}$ levels were below suggested critical levels.

Availability of $\mathrm{P}$ is essential for controlling crop growth and development [29]. Overall, in this study, Pemba district exhibited highest $\mathrm{P}$ content in the top and base termite mound sections including $10 \mathrm{~m}$ away from the structure compared with Choma. However, this was not significant $(p>0.05)$. With this scenario, it would be beneficial for resource constrained smallholder farmers to collect termite mound from the top unlike the base for application in their agriculture fields as there is relatively higher P content. This may be supplemented with cattle manure to enhance the organic matter content of the soil and other limited nutrients. Hernandez et al. [30] reported that feeding and the manner of construction influenced the P content of termite mounds. In the current study however, soils collected $10 \mathrm{~m}$ away from the termite mound had the least concentration of $\mathrm{P}$, attributed to the inherent parent material. Generally, P is one of the limiting nutrients in Southern Zambia. A study by Yerokun [31] also indicated that soils of different origins within the country showed similar lower trends in their amount of available P.

All the studied sites had sufficient $\mathrm{Mg}$ levels, except a few in Choma district, suggesting that to attain optimum crop yield, application of termite mound soil, cattle manure and commercially available fertilizers would provide supplemental $\mathrm{Mg}$.

For most crops grown in southern Africa, Fairhurst [24] recommended $0.2 \mathrm{cmol} \mathrm{kg}^{-1}$ as a critical level of exchangeable $\mathrm{K}$ in soils. Nearly all the soils collected from top and base termite mound had $\mathrm{K}$ levels above critical values compared with those collected $10 \mathrm{~m}$ away from it. One site in Choma district had $\mathrm{K}$ levels below critical value implying that to enhance the $\mathrm{K}$ levels in the deficient area there was need to apply termite mound soil, cattle manure and commercially available fertilizers as supplement for $\mathrm{K}$.

The proposed critical level of Ca for majority of crops was $0.5 \mathrm{cmol} \mathrm{kg}^{-1}$ [24]. All the sites had Ca levels above the suggested critical value, a situation that implied that the cation was the most prominent on the soil colloids. Additionally, Pemba district exhibited highest Ca content in the top termite mound soils in comparison with Choma. Kristiansen et al. [32] observed that termite mounds are enriched with inorganic elements such as $\mathrm{Ca}$, compared with nearby surface soils resulting from the termite mound building ants' collection of various woody debris and foraging activities.

The critical threshold of SOC is pegged at $0.4 \%$ [22]. Anything below this poses a critical loss in soil health which may not support proper crop growth. In this respect, Sarcinelli et al. [16] indicated that higher values of SOC observed in the top termite mounds are attributable to termite action of swallowing soil organic matter which is returned as faecal pellets. Soil organic carbon is a measure of the readily available oxidizable content of organic matter, which directly influences nitrogen supplying capacity of the soil. 
Minasny and Mcbratney [33] asserted that a 1\% mass increase in soil organic carbon (or $10 \mathrm{~g} \mathrm{C} \mathrm{kg}^{-1}$ soil mineral), based on average, increased water content at saturation, field capacity, wilting point and available water capacity by: 2.95, $1.61,0.17$ and $1.16 \mathrm{~mm} \mathrm{H}_{2} \mathrm{O} 100 \mathrm{~mm} \mathrm{soil}^{-1}$, respectively. The increase is reported to be in the order; sandy soils $>$ loams $>$ clays. Chapoto et al. [4] were of the opinion that most of the agricultural lands across southern Africa including Zambia, lacked the much-required organic matter, which is cardinal to the fertility of soils. Absence of required organic matter has negative consequence on the physical, chemical and microbial health of soils. Mtangadura et al. [34] reported that organic nutrient resources which are accessible by smallholder farmers in southern Africa have great potential to enhance soil organic matter despite having differences in their chemical quality and mineral $\mathrm{N}$ fertilization regimes.

CEC averaged $32.2 \mathrm{cmol} \mathrm{kg}^{-1}$ in the top termite mound soil in both studied sites. Fairhurst [24] grouped soils having $<10 \mathrm{cmol} \mathrm{kg}^{-1}$ as inadequate in exchangeable bases. Base termite mound soil exhibited CEC average of $30.09 \mathrm{cmol} \mathrm{kg}^{-1}$ whereas soil collected $10 \mathrm{~m}$ away from the structure had an average of $4.21 \mathrm{cmol} \mathrm{kg}^{-1}$. Most sites had CEC above critical value except for two sites away from the termite mounds in Pemba and Choma districts which were below $10.0 \mathrm{cmol} \mathrm{kg}^{-1}$, the recommended minimum level. Such soils indicated that they have low cation retention capacity for $\mathrm{Ca}^{2+}, \mathrm{K}^{2+}$ and $\mathrm{Mg}^{2+}$. In order to correct the situation, application of organic fertilizers would suffice as they contained high soil organic matter, which is an important source of cation exchange capacity.

The results showed that the termite mound soil had higher values of EC compared with the adjacent soil across the study districts. Knowledge of EC of the soil is important as it renders information about the concentration of soluble salts in the soils. Raina et al. [22] reported that crops like maize, wheat, sorghum and rice among others are medium salt tolerant crops. It is, therefore, a must to have an idea of the salts in a particular soil in order to know its suitability for different crops. Soils with less than $2000 \mu \mathrm{sm}^{-1}$ EC values are considered to have low salinity.

Fageria and Baligar [12] reported that mound termite activities have a significant direct influence on the soil chemical properties which enhances their fertility. Lindsay and Cox [25] proposed critical level for different crops ranging from 0.3 to $10 \mathrm{mg} \mathrm{kg}^{-1}$. In all the studied soils, the Fe levels were above the critical level.

Both the top and base termite mound soils had adequate $\mathrm{Zn}$ levels while soils collected $10 \mathrm{~m}$ away from the structure exhibited Zn deficiency. A study conducted by Manzeke et al. [35] in Zimbabwe indicated that inadequate $\mathrm{Zn}$ levels threatens crop production and food nutrition in most cereal-based cropping systems across Africa, a scenario that was also observed in the studied sites. Steffan et al. [36] stressed that the state of a soil has implications on a particular soil's capability to make available services for growing nutritious foods.

Generally, the relationship between organic carbon and some available mineral elements in various soil collection points ( $\mathrm{n}$ ) differed. This may be attributable to the termite mound building activities' that influence the nutrient cycling regimes in the soil environment [12] (Table 4).

The amounts of clay fractions found in various termite mound sections were similar in magnitude to those observed by other scientists. For instance, a study by Haitao et al. [37], in China, found that the silt and clay content of termite mounds were higher than for adjacent non-termite mound soil. In this regard, ants which are found in termite mounds are responsible for affecting the soil physical characteristics through their activities whereby the small particles are moved from the deeper layers to the surface, burying the organic matter deeper, resulting in changes in soil particle constituents.

These observed differences in textural classes were a result of the original nature of the parent material in studied sites that was mainly composed of sandy. For instance, in a study conducted by Chapoto et al. [4] it was indicated that most of the soils in Agro Ecological Zone IIa, in which the studied areas are located, are of sandy texture. The higher sand percentage in the studied sites gave an indication that the soils were infertile and low in major crop nutrients such as N, P, K and SOC. This conforms with a study conducted by Wyngaard et al. [29] who revealed that most Zambian agricultural soils had inherent small amounts of $P$ in them. The low levels of $P$ availability were linked 
to the low organic matter composition, nature of the soil, exacerbated by the microenvironments where they were found (Figures 3 and 4).

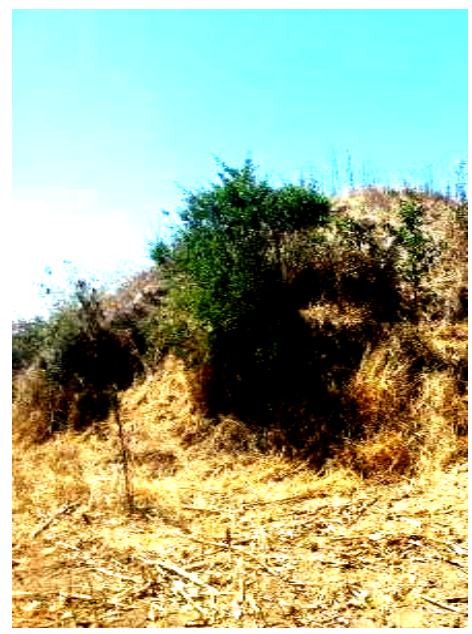

(A)

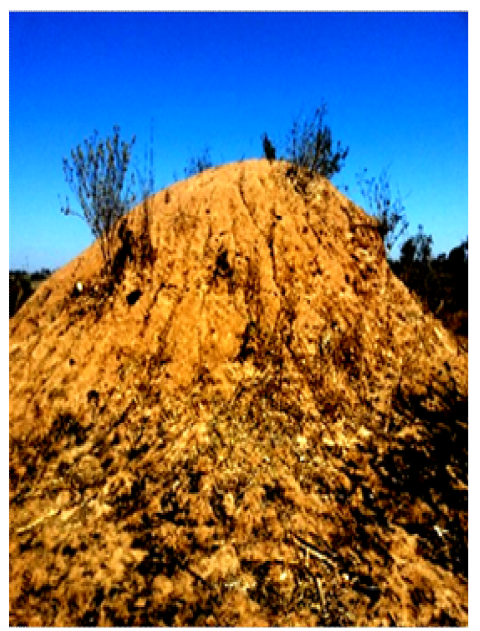

(B)

Figure 3. (A) Termite mound with vegetation cover is an indicator of good fertility; (B) termite mound with no or little vegetation cover depicts poor fertility and is never utilized for agricultural production as part of low input nutrient management strategy by smallholder farmers in Southern Zambia. Indigenous knowledge is normally applied by the mound soil users to identify suitability in crop production [7].

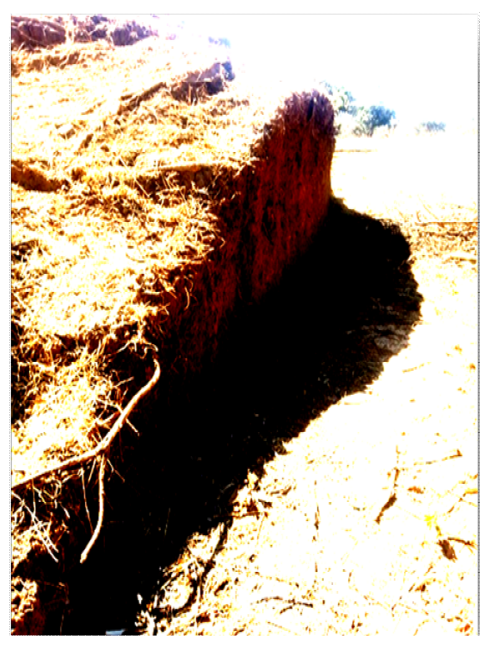

(A)

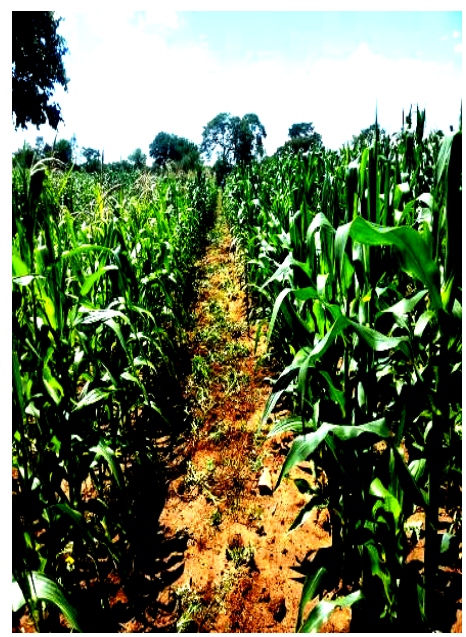

(B)

Figure 4. (A) Part of cut termite mound soil applied for fertility improvement; (B) Maize crop under termite mound soil treatment as part of integrated nutrient management in a conservation agricultural system, Southern Zambia.

\section{Conclusions}

The study demonstrated that soil from the top and base sections of the termite mound structures in Southern Zambia, contain potential macro and micro nutrients ( $\mathrm{P}, \mathrm{K}, \mathrm{Ca}, \mathrm{Mg}, \mathrm{Cu}, \mathrm{Fe}$ and $\mathrm{Zn}$ ) which can substantially support crop growth. This can play a key role in integrated nutrient management systems, where manure, crop rotation, intercropping or application of commercially available fertilizer may be used to boost $\mathrm{N}$ and $\mathrm{P}$ levels in soils lacking these nutrients. 
Top sections of the termite mounds exhibited more fertility than the base and the neighbouring soils. This may be attributed to the foraging activities of ants responsible for building termite mounds. During formation, the ants collect organic materials from the surrounding areas and use it for constructing the termite mounds thereby enriching them with nutrients.

In view of the above, we recommend that future studies should focus on growing crops using soil collected from different sections, top and base of the termite mounds and establish the performance under such soil amendment conditions. There is also a need to determine at least optimal rates of termite mound soil for application in agricultural fields especially under conservation agricultural systems to boost crop production and productivity in combination with organic and commercially available mineral fertilizer.

Author Contributions: Conceptualization, K.C. and P.A.N.; methodology, K.C.; software, K.C.; validation, P.A.N. and E.R.M.; formal analysis, K.C.; investigation, K.C.; resources, K.C, E.R.M. and P.A.N.; data curation, K.C.; writing-original draft preparation, K.C.; writing-review and editing, P.A.N. and E.R.M.; visualization, K.C.; supervision, P.A.N. and E.R.M.; project administration, P.A.N.; funding acquisition, K.C, E.R.M. and P.A.N. All authors have read and agreed to the published version of the manuscript.

Funding: This research was partially funded by the World Bank through the Centre for Research, Agricultural Advancement, Teaching Excellence and Sustainability in Food and Nutritional Security (CREATES-FNS) of the Nelson Mandela African Institution of Science and Technology, Arusha, Tanzania, grant number 5799-TZ and the Pilot Programme for Climate Resilience, Ministry of National Development Planning, Lusaka, Zambia.

Acknowledgments: We are grateful to the Department of Agriculture (Zambia) and farmers for assistance during soil sampling in research sites.

Conflicts of Interest: The authors declare no conflict of interest.

\section{References}

1. FAO. FAO Status of the World's Soil Resources (SWSR)—Technical Summary; Food and Agriculture Organization: Rome, Italy, 2015.

2. Umar, B.B.; Aune, J.B.; Lungu, O.I. Effects of Faidherbia albida on the fertility of soil in smallholder conservation agriculture systems in eastern and sourhen Zambia. Afr. J. Agric. Res. 2013, 8, 173-183.

3. Sileshi, G.W.; Nyeko, P.; Nkunika, P.O.Y.; Sekematte, B.M.; Akinnifesi, F.K.; Ajayi, O.C. Integrating Ethno-Ecological and Scientific Knowledge of Termites for Sustainable Termite Management and Human Welfare in Africa. Ecol. Soc. 2009, 14, 48. [CrossRef]

4. Chapoto, A.; Chabala, L.M.; Lungu, O.N. Long History of Low Productivity in Zambia: Is it Time to Do Away With Blanket Recommendations; IAPRI: Lusaka, Zambia, 2016.

5. Mtambanengwe, F.; Mapfumo, P. Combating food insecurity on sandy soils in Zimbabwe: The legume challenge. Symbiosis 2009, 48, 25-36. [CrossRef]

6. Siame, J.A. Termite mounds as Fertilizer. LEISA 2005, 7, 27.

7. Chisanga, K.; Mbega, E.; Ndakidemi, P. Socio-Economic Factors for Anthill Soil Utilization by Smallholder Farmers in Zambia. Sustainability 2019, 11, 4849. [CrossRef]

8. Ruiz-Diez, B.; Fajardo, S.; Puertas-Mejia, M.A.; de Felipe Mdel, R.; Fernandez-Pascual, M. Stress tolerance, genetic analysis and symbiotic properties of root-nodulating bacteria isolated from Mediterranean leguminous shrubs in Central Spain. Arch. Microbiol. 2009, 191, 35-46. [CrossRef]

9. Nziguheba, G.; Zingore, S.; Kihara, J.; Merckx, R.; Njoroge, S.; Otinga, A.; Vandamme, E.; Vanlauwe, B. Phosphorus in smallholder farming systems of sub-Saharan Africa: Implications for agricultural intensification. Nutr. Cycl. Agroecosystems 2016, 104, 321-340. [CrossRef]

10. Otinga, A. Coping with Phosphorus Limitations: Allocation of P in Maize Based Cropping Systems in Western Kenya. Ph.D. Thesis, Katholieke Universiteit Leuven, Leuven, Belgium, 2012.

11. Pérez-Fernández, M.; Míguez-Montero, Á.; Valentine, A. Phosphorus and Nitrogen Modulate Plant Performance in Shrubby Legumes from the Iberian Peninsula. Plants 2019, 8, 334. [CrossRef]

12. Fageria, N.K.; Baligar, V.C. Properties of Termite Mound Soils and Responses of Rice and Bean to Nitrogen, Phosphorus, and Potassium Fertilization on such Soil. Commun. Soil Sci. Plant Anal. 2005, 35, 2097-2109. [CrossRef] 
13. Ministry of Tourism, Environment and Natural Resources. Zambia National Action Programme for Combating Desertification \& Mitigating serious Effects of Drought in the Context of the United Nations Convention to Combat Desertification; Ministry of Science, Technology and Vocational Training: Lusaka, Zambia, 2002.

14. Roland, B.; Oscar, S.; Christoph, N. Groundwater Resources for Southern Province, Brief Description of Physiography, Climate, Hydrology, Geology and Groundwater Systems of the Southern Province; Ministry of Energy and Water Development: Lusaka, Zambia, 2007.

15. Nkem, J.N.; Lobry de Bruyn, L.A.; Grant, C.D.; Hulugalle, N.R. The impact of ant bioturbation and foraging activities on surrounding soil properties. Pedobiologia 2000, 44, 609-621. [CrossRef]

16. Sarcinelli, T.S.; Shaefer, C.E.G.R.; Lynch, L.S.; Arato, H.D.; Viana, J.H.M.; Filho, M.R.A.; Goncalves, T.T. Chemical, physical and micromorphological properties of termite mounds and adjacent soils along a toposequence in Zona da Mata. Catena 2009, 76, 107-113. [CrossRef]

17. VanReeuwijk, L.P. Procedure for Soil Analysis; International Soil Reference and Information Centre (ISRIC): Wageningen, The Netherlands, 1993.

18. Walkley, A.; Black, I.A. An examination of the Degtjareff method for determining soil organic matter and a proposed modification of the chromic acid titration method. Soil Sci. 1934, 37, 29-38. [CrossRef]

19. Page, A.L. Method of Soil Analysis, Part 2, Chemical and Microbiological Properties; American Society of Agronomy: Madison, WI, USA, 1982.

20. Bray, R.H.; Kurtz, L.T. Determination of Total, Organic, and Available Forms of Phosphorus in Soils. Soil Sci. 1945, 59, 39-46. [CrossRef]

21. VanReeuwijk, L.P. Procedures for Soil Analysis; International Soil Reference and Information Centre (ISRIC)-World Information: Wageningen, The Netherlands, 2006.

22. Raina, J.N.; Sharma, J.C.; Sharma, I.P. Manual on Methods for Physical and Chemical Analysis of Soils; Department of Soil Science and Water Management, Dr Y.S Parmar University of Horticulture and Forestry: Nauni, India, 2007.

23. Wang, T.; DeVogel, N. A revisit to two-way factorial ANOVA with mixed effects and interactions. Commun. Stat. Theory Methods 2019, 1-18. [CrossRef]

24. Fairhurst, T. Handbook for Integrated Soil Fertility Management; Africa Soil Health Consortium: Nairobi, Kenya, 2012.

25. Lindsay, W.L.; Cox, F.R. Micronutrient Soil Testing for the Tropics. In Micronutrients in Tropical Food Crop Production; Springer: Dordrecht, The Netherlands, 1985; pp. 169-200.

26. Silanpaa, N. Micronutrients and Nutrient Status of Soils: A Global Study. In FAO Soil Bulletin; FAO: Rome, Italy, 1982.

27. Mtambanengwe, F.; Mapfumo, P. Effects of organic resource quality on soil profile $\mathrm{N}$ dynamics and maize yields on sandy soils in Zimbabwe. Plant Soil 2006, 281, 173-191. [CrossRef]

28. Ndakidemi, P.A.; Semoka, J.M.R. Soil Fertility Survey in Western Usambara Mountain, Northern Tanzania. Pedosphere 2006, 16, 237-244. [CrossRef]

29. Wyngaard, N.; Cabrera, M.L.; Jarosch, K.A.; Bunemann, E.K. Phosphorous in the coarse soil fraction is related to soil organic phosphorous mineralization measured by isotopic dilution. Soil Biol. Biochem. 2016, 96, 107-118. [CrossRef]

30. Hernandez, D.L.; Brossard, M.; Fardeau, J.C.; Lepage, M. Effect of different termite feeding groups on P sorption and P availability in African and South American savannas. Biol. Fertil. Soils 2006, 42, 207-214. [CrossRef]

31. Yerokun, O. Chemical characteristics of phosphorous in some representative benchmark soils of Zambia. Geoderma 2008, 147, 63-68. [CrossRef]

32. Kristiansen, S.M.; Amelung, W.; Zech, W. Phosphorous forms as affected by abandoned anthills (Formica polyctena Forster) in forest soils: Sequential extraction and liquid-state 31P-NMR spectroscopy. J. Plant Nutr. Soil Sci. 2001, 164, 49-55. [CrossRef]

33. Minasny, B.; Mcbratney, A.B. Limited effect of organic matter on soil available water capacity:Limited effect of organic matter on soil water retention. Eur. J. Soil Sci. 2017, 69, 39-47.

34. Mtangadura, T.J.; Mtambanengwe, F.; Nezomba, H.; Rurinda, J.; Mapfumo, P. Why organic resources and current fertilizer formulations in Southern Africa cannot sustain maize productivity: Evidence from a long-term experiment in Zimbabwe. PLoS ONE 2017, 12, e0182840. [CrossRef] [PubMed] 
35. Manzeke, G.M.; Mapfumo, P.; Mtambanengwe, F.; Chikowo, R.; Tendayi, T.; Cakmak, I. Soil fertility management effects on maize productivity and grain zinc content in smallholder farming systems of Zimbabwe. Plant Soil 2012, 361, 57-69. [CrossRef]

36. Steffan, J.J.; Brevik, E.C.; Burgess, L.C.; Cerda, A. The effect of soil on human health: An overview. Eur. J. Soil Sci. 2017, 69, 159-171. [CrossRef] [PubMed]

37. Haitao, W.; Donghui, W.; Xianguo, L.; Xiaomin, Y. Spatial distribution of ant mounds and effects on soil physical properties in wetland of the Sanjiang plain China. Acta Ecol. Sin. 2010, 30, 270-275.

(C) 2020 by the authors. Licensee MDPI, Basel, Switzerland. This article is an open access article distributed under the terms and conditions of the Creative Commons Attribution (CC BY) license (http://creativecommons.org/licenses/by/4.0/). 